\title{
Chapeuzinho Vermelho no Divã
}

Ivan Vale de Sousa ${ }^{1}$

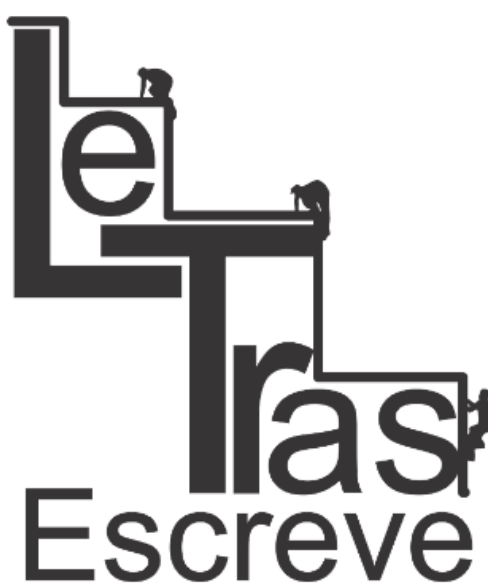

(ISSN 2238-8060)
Resumo: É inegável que os contos de fadas compõem parte da infância das crianças e que a arte de contar histórias Ihes atrai e traz algum tipo de ensinamento, além disso, contribuem com a formação lúdica infantil e possibilita a ampliação do processo leitor. Nesse sentido, este trabalho objetiva evidenciar de forma sucinta as instâncias da psique humana na concepção da criança, discutir sobre a importância dos contos de fadas na formação leitora na infância, refletir à luz da psicanálise as contribuições que essas histórias conferem ao desenvolvimento infantil, elucidar as semelhanças e as diferenças encontradas no conto Chapeuzinho Vermelho, de Charles Perrault, traduzido e adaptado por Monteiro Lobato (2002) e Walcyr Carrasco (2009), realizando uma comparação entre as abordagens adaptadas por Lobato e Carrasco, além de demonstrar de que forma a psicanálise coopera com o processo de compreensão do professor e, consequentemente, com o desenvolvimento emocional da criança. A essência deste trabalho é de natureza bibliográfico-analítica e reflexiva tomando por base duas versões de uma mesma narrativa. Assim, esperase que as discussões evidenciadas nesta produção possam subsidiar a realização do trabalho docente à luz da psicanálise no contexto escolar.

Palavras-chave: Contos de fadas. Charles Perrault. Psicanálise. Formação leitora.

Abstract: It is undeniable that fairy tales make up part of the childhood of the children and the art of storytelling attracts them and brings some kind of teaching also contribute to child playful training and enables the expansion of the reader process. In this sense, this work aims to show succinctly instances of the human psyche in the child's conception, discuss the importance of fairy tales in reader training in childhood, reflect the light of psychoanalysis contributions that these stories give the child development, elucidating the similarities and differences found in the Little Red Riding Hood tale by Charles Perrault, translated and adapted by Monteiro Lobato (2002) and Walcyr Carrasco (2009), performing a comparison between the approaches adapted by Lobato and Carrasco, and demonstrate how the psychoanalysis cooperates with the teacher's understanding of the process and, consequently, the child's emotional development. The essence of this work is literature-analytical and reflective nature building on two versions of the same narrative. Thus, it is expected that the discussions highlighted in this production can support the realization of teaching in the light of psychoanalysis in the school context.

Keywords: Fairy tale. Charles Perrault. Psychoanalysis. Reader training.

\footnotetext{
1 Mestrando em Letras no Instituto de Linguística, Letras e Artes da Universidade Federal do Sul e Sudeste do Pará (UNIFESSPA). Integrante do Grupo de Pesquisa Práticas de Linguagens em Estágios Supervisionados (PLES), da Universidade Federal do Tocantins (UFT). Email: ivan.valle.de.sousa@gmail.com
}

https://periodicos.unifap.br/index.php/letras

Macapá, v. 6, n. I, Io semestre, 2016. 


\section{Introdução}

Os contos de fadas apresentam significativas relevâncias no processo de formação e imaginação da criança, por meio deles, é possível compreender os ensinamentos que estão inseridos no enredo da história. Além disso, permite ao sujeito a percepção de que há ensinamentos com base na atuação das personagens e isso, muitas vezes, propõe uma identificação com os elementos presentes na narrativa.

As histórias infantis representam para as crianças a possibilidade de se perceberem como atuantes no processo de interação com o conto. Do mesmo modo, os contos de fadas têm sido utilizados, sobretudo, pelas instituições de Educação Infantil como formas de permitir o contato com a literatura aos sujeitos em início das situações de aprendizagem. O que boa parte dos professores não compreendem é que na efetivação dessas narrativas há a presença das estruturas formadoras da psique humana, entendidas como: id, ego e superego.

A narratividade dos contos de fadas remonta aos tempos de outrora, pois, com o passar dos anos, essas histórias, vêm sendo traduzidas e adaptadas à linguagem e à compreensão da criança. Nessas narrações é comum a sobreposição do ódio, da cobiça, da invídia, da superação, do mal, mas, também do belo e do bem. Embora sendo narrativas muito antigas são consideradas verdadeiras obras de arte na acessibilidade ao mundo literário por parte da criança.

De tal modo, este trabalho realiza está dividido em dois tópicos discursivos, a saber: no primeiro são apresentadas sucintamente reflexões sobre a psique humana, como também a relevância da literatura infantil na formação identitária da criança. $\mathrm{Na}$ segunda parte é apresentado um estudo comparativo entre duas versões do conto Chapeuzinho Vermelho, de Charles Perrault, 
adaptado pelo escritor pré-modernista Monteiro Lobato e pelo pósmoderno Walcyr Carrasco.

Além disso, são elucidadas algumas contribuições sob o ponto de vista da psicanálise com base nas reflexões de Bruno Bettelheim (2015), destacando-as na relação professor e aluno no contexto educacional, de modo que aquele compreenda o desenvolvimento emocional deste, destacando, ainda, a utilidade dos contos de fadas na formação de crianças em fase de alfabetização, sendo, pois, uma das maneiras de possibilitar-Ihes o acesso e o convívio com a literatura infantil.

\section{Psique humana e literatura infantil: reflexões acerca da formação identitária da criança}

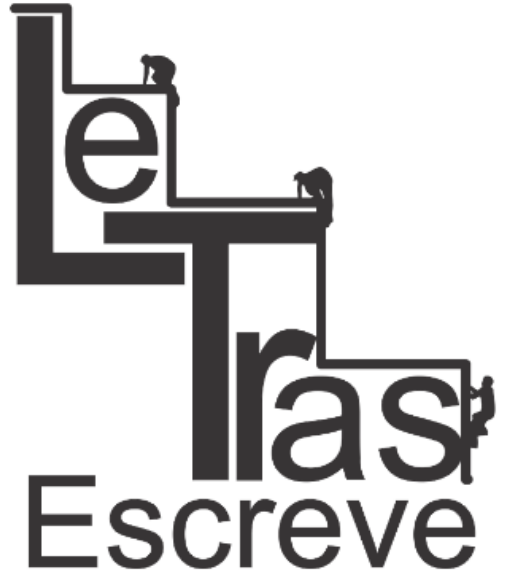

(ISSN 2238-8060)

A mente humana tem sido por muito tempo e (continua sendo) objeto de estudo no que se refere ao seu processo de compreensão. Entendê-la não é uma tarefa fácil e que não ocorre no acaso, é preciso, antes de tudo, muito estudo e formação para que se tenha um olhar ampliado sobre as estruturas que formam o pensamento humano. As teorias da personalidade humana têm seu destaque nos estudos de Sigmund Freud (1856-1939) que se debruçou no entendimento dos estágios da psique humana. Essas estruturas mentais são conhecidas como: id, ego e superego. Eles fazem parte da existência humana, sobretudo, no processo de formação da criança.

O Id compreende os instintos e seus impulsos, os quais estão presentes em nossas vidas desde o nascimento. O Ego desenvolve-se a partir do Id e é sem sombra de dúvidas a estrutura mais conhecida. Pode-se dizer que o Ego é uma parte do Id que foi modificada pela influência direta do mundo externo. O Superego forma-se em conformidade com as regras, valores e educação que recebemos durante nosso desenvolvimento. Corresponde às funções morais e normativas de nossa personalidade como autoestima, autoelogio, autoobservação crítica, aprovações e desaprovações de ações e

https://periodicos.unifap.br/index.php/letras

Macapá, v. 6, n. I, Io semestre, 2016. 
desejos, arrependimento e reparação de ações, etc. (VOLPI, 2008, p. 1-2)

A compreensão dessas estruturas no processo formativo da criança é relevante tanto para o convívio, para as descobertas, quanto para a abordagem educacional. Esses estágios pelos quais todo ser humano passa contribuem na formação da identidade humana, assim, a psique, nesse sentido, precisa ser compreendida de modo a refletir acerca dessas estruturas funcionais e os contos de fadas cumprem essa função à luz da psicanálise, até porque todos os ensinamentos presentes nas narrativas infantis trazem uma série de contextos que carecem ser entendidos pelos adultos.

Os contos de fadas encantam porque permitem a ampliação do pensamento infantil e a sua riqueza e efetivação estão,

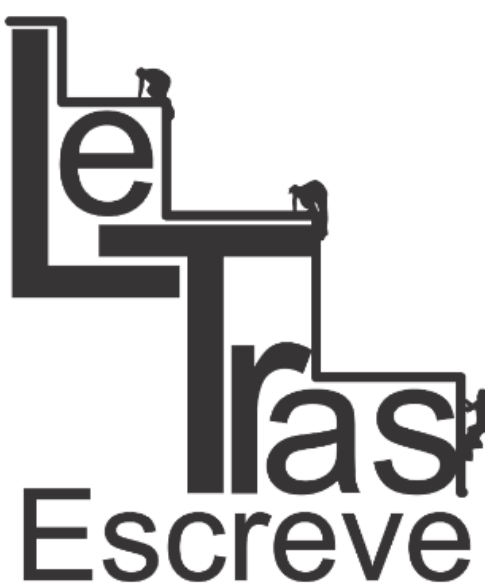

(ISSN 2238-8060) exatamente, na compreensão que a criança realiza ao ouvir ou realizar a leitura de uma história nessa perspectiva. É preciso que ele mesma busque referências para compreender o enredo narrado e, muitas vezes, há uma quebra dessa busca quando há demasiadamente uma explicação por parte do adulto, o que viabiliza o rompimento encantador e valor simbólico, deixando de ser interessante para a criança. Sabe-se que boa parte dos contos infantis traz um ensinamento implícito, contudo, a sua função primordial no contexto da aprendizagem não é apenas transmitir uma lição moralista, porém permitir que a criança construa um diálogo com o que está sendo narrado.

A simbologia contida em cada conto possibilita que a criança ouvinte ou leitora construa pontes interativas entre os acontecimentos descritos na obra e seu mundo imaginário. Assim sendo, por meio da leitura dessas histórias é possível "descobrir outros lugares, outros tempos, outros jeitos de agir e de ser, outras regras, outra ética, outra ótica. É ficar sabendo história, filosofia, direito, política, sociologia, antropologia, etc., sem precisar saber o nome disso tudo e muito menos achar que tem cara de aula". (ABRAMOVICH, 2006, p. 17) 


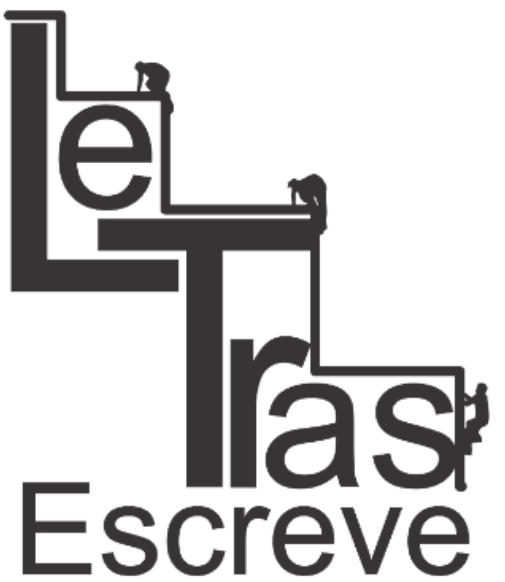

(ISSN 2238-8060)
O caráter formativo dos contos de fadas está, exatamente, em possibilitar por meio da leitura ou da arte de contar histórias à criança, ela, consiga construir seu mundo simbólico, criar suas convicções e com isso aguçar sua curiosidade e criatividade no deleite proporcionado pela atmosfera advinda da narrativa. Os significados atribuídos por ela aos acontecimentos dessas histórias estão, justamente, em conseguir criar outras simbologias das apresentadas nos contos, mantendo um processo de interação com as personagens, o que muitas vezes, a leva a se identificar com algumas delas.

Os contos de fadas se valem da descrição das personagens e do contexto em que elas estão inseridas e essa característica permite à criança a utilização dos sentidos perceptuais (visão, audição, olfato, tato, paladar). A sua relação com a narrativa elucidada encontra-se a partir da simplicidade descritiva dos seres que compõem o texto, por isso, deve-se sempre pensar na adaptação da narrativa direcionada para determinados níveis de compreensão, de modo que tanto o leitor quanto o ouvinte sejam capazes de criar suas convicções acerca dos elementos inerentes à história, contribuindo, dessa forma, com a ampliação do pensamento.

Imaginar não é só pensar, não significa apenas relacionar fatos, e analisar situações, tirando-lhe significados. Imaginar é penetrar, explorar fatos dos quais se retira uma visão. Esta só poderá ser comunicada ao outro através de símbolos, que provocam harmônicos e estabelecem a comunhão. O símbolo age como mediador para revelar ocultando, ocultar revelando, e ao mesmo tempo, incitar à participação que, embora com impedimentos e obstáculos, fica favorecida. (POSTIC, 1993, p. 19)

A literatura infantil, nesse sentido, deve ser carregada de uma linguagem simples o que não impede o uso de algumas metáforas que direcionem a compreensão da criança em um estágio mais elevado da narrativa. Produzir literatura para o público infantil não é uma tarefa fácil, uma vez que exige do escritor conhecimento de 


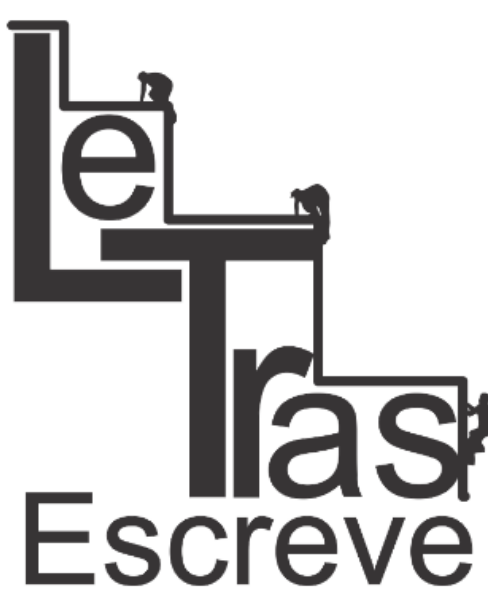

(ISSN 2238-8060)

causa e sensibilidade na organização dos elementos narrados. Para subsidiar a produção literária em prol da criança, alguns questionamentos devem ser levados em consideração na proposição de uma literatura que atenda os seus anseios, como: qual será a problemática que norteará a produção? Que tipo de linguagem deve ser empregada? Como as palavras se organizam na narrativa? Qual concepção de criança a obra será pensada? Como a criança entenderá o que um adulto escreve na sua concepção e conhecimento de mundo? De que forma devem ser mantidas a estética e a poética no encadeamento das ideias que se elucidam no texto? Quais elementos utilizar para direcioná-la na construção de um mundo simbólico? O que o autor entende por fantasia? E como propor isso no escopo da narrativa?

De posse das indagações, conclui-se que produzir para o público infantil é uma tarefa cercada de desafios, visto que, o foco narrativo necessita fortalecer e aguçar o que é inerente à criança: encantamento e imaginação. É preciso, pois, caracterizar os contos de fadas com a ideia de fatos ocorridos, por isso, que a maioria dessas histórias se vale das construções seguintes iniciais: "era uma vez", "num reino distante", há muito tempo", "conta-se que", etc., daí a importância da utilização da oralidade. Esta representa o primeiro contato que a criança tem com o mundo literário e na chamada arte de contar e recontar histórias, o sujeito contante ostenta a função de narrador.

A contação de histórias pode ser de maneira lúdica, fácil, e subliminar, porque ela atua sobre seus pequenos leitores, levando-os a perceber e a interrogar a si mesmos e ao mundo que os rodeia, orientando seus interesses, suas aspirações, sua necessidade de autoafirmação, ao Ihes propor objetivos, ideias ou formas possíveis (ou desejáveis) de participação no mundo que os rodeia. (COELHO, 2003, p. 123)

Contar histórias é arte e, de todo modo, precisa ser aperfeiçoada, pois, ao oralizar os acontecimentos presentes no texto para o público infantil é necessário envolvê-lo na atmosfera dos

https://periodicos.unifap.br/index.php/letras

Macapá, v. 6, n. I, Io semestre, 2016. 
episódios narrados, propondo algumas inferências que agucem a curiosidade, desperte a atenção e o envolva no contexto mágico da narrativa. Assim, revisitar a funcionalidade dos contos de fadas é uma questão necessária às novas gerações, além do valor simbólico, representa, ainda, um passaporte para o mundo literário e Ihes desperta para a leitura. De tal modo, os contos de fadas são acessos à compreensão do mundo simbólico construído pela criança e, ao professor, à luz da psicanálise, cabe compreendê-los e utilizálos no processo de ensino-aprendizagem.

\section{O Conto de fadas Chapeuzinho Vermelho numa ótica comparativa}

A origem dos contos de fadas é muito antiga, mas mesmo assim as narrativas elucidadas nessas histórias continuam encantando gerações. Vários são os contos que passam por um processo de adaptação para outras linguagens artísticas, como é o caso do cinema, entre elas: A Branca de neve e os sete anões, A Gata borralheira, Cinderela, Chapeuzinho Vermelho, entre outros contos. A riqueza no processo de adaptação está ligada à concepção do profissional e de seu conhecimento de mundo. Assim, contam algumas versões que uma menina doce e gentil precisava ir até à casa de sua avó a mando de sua genitora, levar algumas frutas e doces à velhinha que se encontrava enferma. A visita é rodeada de perigos, aventuras e encantos que a floresta escondia. Essa narrativa representa perfeitamente $o$ ponto de partida para a realização deste trabalho.

As reflexões que serão pontuadas a seguir referem-se à tradução do conto Chapeuzinho Vermelho, de Charles Perrault, evidenciada pelo imortal da Academia Brasileira de Letras ( $A B L$ ), Monteiro Lobato, com adaptação também do escritor pós-modernista Walcyr Carrasco, membro da $\mathrm{ABL}$, na qual se destacarão algumas diferenças e semelhanças na versão do conto de fadas em pauta.

https://periodicos.unifap.br/index.php/letras Macapá, v. 6, n. I, Io semestre, 2016. 


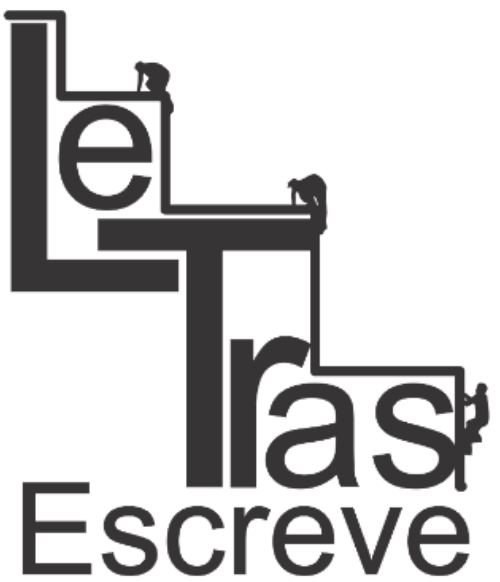

(ISSN 2238-8060)

$\mathrm{Na}$ adaptação de Lobato, o conto, inicia-se com o verbo 'ser' no pretérito mais-que-perfeito do modo indicativo, fundamental característica principiadora das narrativas destinadas às crianças. Nesse sentido, a história estreia da seguinte forma: "Era uma vez uma menina linda, que morava numa aldeia com sua mãe. Chamava-se Capinha Vermelha, por causa duma capinha dessa cor que sua avó lhe havia feito" (LOBATO, 2002, p. 7). E, a partir desse início, o conto segue com sua trama em que a menina vive suas aventuras, encantos e desencantos até conseguir chegar à casa da velhinha.

A tradução apresentada por Carrasco (2009) inicia diferentemente da versão exposta por Lobato (2002). Por ser um escritor mais contemporâneo, aquele toma como ponto de partida a apresentação do contexto do conto. Assim sendo, na versão, segundo Carrasco, a história inicia-se conforme observada no excerto abaixo.

Nos tempos em que as pessoas moravam em aldeias pequenas, cercadas por florestas, vivia uma linda menina, adorada pela mãe e pela avó. Tinha uma capinha vermelha com um chapeuzinho que não tirava nunca. Logo, passou a ser conhecida pelo apelido de Chapeuzinho Vermelho. Sua avó morava longe de sua casa, em outra aldeia, em uma cabana muito próxima à floresta, onde era possível chegar por um caminho que contornava as árvores. A floresta, porém, não era tão perigosa como pode parecer para nós, habitantes de cidades, capazes de nos assustar diante de qualquer bicho do mato. Chapeuzinho Vermelho estava acostumada a passear pelos bosques com o pai e a mãe. Por isso, a história que se segue não é de se estranhar. (CARRASCO, 2009, p. 1)

Embora o conto de Chapeuzinho Vermelho se inicie de maneira diferenciada da versão traduzida por Monteiro Lobato, os elementos que caracterizam a história são mantidos, ou seja, o contexto e, principalmente, a personagem principal da trama. Contudo, considera-se importante que na abordagem de Carrasco há uma descrição da indumentária de Chapeuzinho Vermelho, pois, descreve com precisão que na capinha de cor vermelha utilizada

https://periodicos.unifap.br/index.php/letras

Macapá, v. 6, n. I, Io semestre, 2016. 
pela personagem havia um chapeuzinho da mesma tonalidade e, por isso, passou a ser chamada como a conhecemos.

Dada a intenção deste trabalho que é fazer uma comparação da narrativa de Chapeuzinho Vermelho sob a ótica de dois escritores de épocas diferentes, a seguir serão apresentadas algumas diferenças que podem ser percebidas nas duas versões do mesmo conto. Para isso, far-se-á necessária a utilização de um quadro comparativo elucidando essas altercações.

Quadro 1: DIFERENÇAS EM CHAPEUZINHO VERMELHO

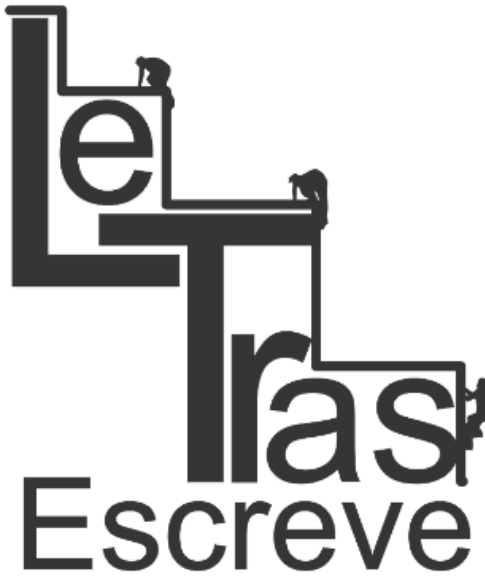

(ISSN 2238-8060)

Monteiro Lobato

- O título é caracterizado de Capinha Vermelha.

- Capinha Vermelha leva bolos e um pouco de manteiga.

- O lobo resolve também visitar a vovó que estava doente.

- O lobo virou a tramela, abriu a porta e entrou e avançou para a velha e a comeu num instante.

- Fechou a porta e foi deitar-se na cama da velha a fim de esperar pela menina.

- O lobo sugere que Capinha Vermelha guarde os bolos e a manteiga no armário e vá conversar com ele.

- A menina guardou o presente, tirou a capinha e dirigiu-se para a cama da velha.

- Ficou logo admirada de ver como era sua avó quando ficava de cama.

Fonte: Perrault/ Lobato (2002); Carrasco (2009)

Walcyr Carrasco

- O título da história é caracterizado de Chapeuzinho Vermelho.

- Chapeuzinho levou uma cesta de doces e pães.

- O lobo disparou pela trilha mais curta e logo chegou na casa da vovó.

- O lobo abriu. Saltou para dentro. Ao vê-lo, a avó arregalou os olhos de susto. Não teve tempo de gritar. O lobo atirou-se sobre ela e devorou-a com uma só dentada.

- Vestiu a camisola e o gorro da avó e deitou-se na cama, à espera da menina.

- Chapeuzinho pôs a cesta ao lado da cama.

- Olhou para a avó. A janela estava fechada. Na penumbra, percebeu que havia algo estranho. Surpreendeu-se.

O desenvolvimento do conto é seguido a partir dos questionamentos realizados por Chapeuzinho, que nas duas traduções são praticamente as mesmas. A partir das indagações realizadas pela menina, o lobo se irrita e, consequentemente, a devora. Assim, os contos de fadas "deixam para a própria fantasia da criança a decisão de se e como aplicar a si própria aquilo que a

https://periodicos.unifap.br/index.php/letras

Macapá, v. 6, n. I, Io semestre, 2016. 


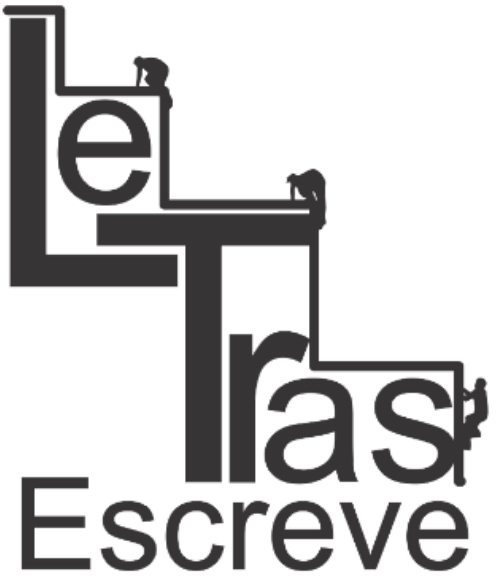

(ISSN 2238-8060) história revela sobre a vida e a natureza humanas" (BETTELHEIM, 2015, p. 67).

A importância de permitir que a criança tenha a chance de compreender o enredo dos contos de fadas parte da capacidade de ensinar por meio dessas histórias uma lição como é o caso em Chapeuzinho Vermelho que mesmo ouvindo sua mãe, não seguiu perfeitamente as orientações maternas. Por isso, uma das maneiras de ensinar é a partir da utilização lúdica presente nas histórias infantis, visto que "uma criança confia no que o conto de fadas diz porque a visão de mundo aí apresentada está de acordo com a sua" (BETTELHEIM, 2015, p. 67).

Em ambas as versões traduzidas pelos autores, a menina que tem por nome sua principal maneira de vestir-se, desobedece sua mãe e se deixa envolver pelas palavras do Lobo, deixando-se convencer. A garota desvirtua-se do caminho indicado por sua genitora e envolve-se pelos encantos da floresta, fazendo com isso, atrasar sua chegada à casa de sua avó e, meio que inocente, revela ao animal o que levava na cesta, assim como seu destino. A astúcia do Lobo a convence de que ela deveria seguir por outro caminho para que ele tivesse mais tempo de chegar ao propósito projetado pela menina e, se preparasse para devorá-la, porém só não o fizera antes porque havia a presença de alguns lenhadores nas proximidades.

É importante considerar que a figura do Lobo representa no contexto do conto o perigo e a sedução. Nessa concepção, os contos permitem às crianças a identificação com algumas personagens, pois, assim como as pessoas, os demais elementos assumem características humanas $e$ isso lhes possibilita a aproximação com o desenrolar da narrativa.

No pensamento animista, não só os animais sentem e pensam como nós, mas até mesmo as pedras estão vivas; de modo que ser transformado numa pedra quer dizer simplesmente ter que permanecer silencioso e imóvel por algum tempo. Pelo mesmo

https://periodicos.unifap.br/index.php/letras

Macapá, v. 6, n. I, Io semestre, 2016. 


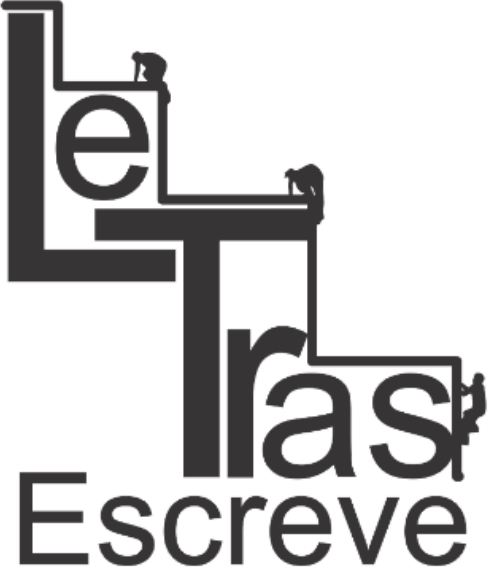

(ISSN 2238-8060) raciocínio, é absolutamente crível quando objetos até então silenciosos começam a falar, dão conselhos e se juntam ao herói em suas andanças. (BETTELHEIM, 2015, p. 69)

A necessidade de magia da criança é um quesito fundamental para que aos poucos ela possa compreender as adversidades da vida. Os contos de fadas, nessa perspectiva, cumprem essa função de ensinar por meio do lúdico, permitindo que a compreensão infantil aos poucos se amplie, a forma como as crianças se percebem e se veem no mundo também se estende, já que, elas não tendo os seus "ids sob controle consciente, necessitam de histórias que permitam pelo menos uma satisfação fantasiosa dessas tendências 'más', e modelos específicos para a sublimação" (BETTELHEIM, 2015, p. 76) e, por isso, vislumbram nos contos de fadas essa possibilidade.

De tal modo, o trabalho com os contos de fadas destinado ao ensinamento de crianças atinge seu propósito, desde que sejam permitidas a elas as condições de pensar a narrativa a partir de si mesmas, pois, quando há o processo de explicação da trama, há a perda do valor simbólico, fato atrativo à compreensão infantil. Entende-se, com isso que o sentido é quebrado quando se tenta esclarecer a significação da narrativa, visto que é preciso permitir que as descobertas aconteçam gradualmente e pela própria criança, que ela de fato vivencie sua fase que se concretiza por meio da simbologia.

À medida que cresce, a criança descobre novos aspectos desses contos bem conhecidos, e isso lhe dá a convicção de que realmente amadureceu em compreensão, uma vez que a mesma história agora lhe revela muito mais. Isso só pode ocorrer se não a tiverem informado didaticamente daquilo que a história supostamente trata. O conto de fadas só alcança um sentido pleno para a criança quando é ela quem descobre espontânea e intuitivamente seus significados previamente ocultos. Essa descoberta faz com que uma história passe de algo que é dado à criança a algo que ela em parte cria para si própria. (BETTELHEIM, 2015, p. 238)

$\mathrm{Na}$ versão apresentada por Carrasco, Chapeuzinho Vermelho, após ser ludibriada pelo Lobo a seguir o caminho indicado por ele, 


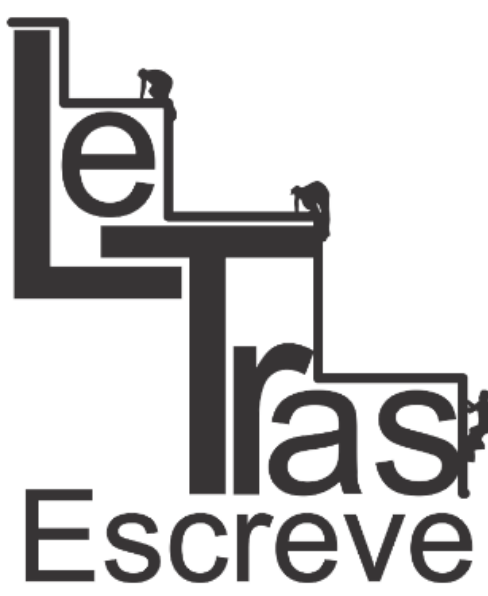

(ISSN 2238-8060) desconsiderando as orientações maternas, é convencida que andar pela floresta poderia ser um passeio divertido cheio de encantos. Nessa perspectiva, a garota "tomou o caminho mais comprido. Ainda mais, distraiu-se perseguindo passarinhos, apanhando frutos do mato e colhendo flores" (CARRASCO, 2009, p. 4), enquanto Chapeuzinho se envolvia pelos encantos do bosque, brincando com os pássaros e colhendo flores diversas, o animal astuto aproveitou para percorrer o caminho mais curto e o quanto antes chegar à casa da velhinha.

Já na tradução evidenciada por Lobato, o animal, apenas sugere um jogo para ver quem dos dois chegaria primeiro à casa da boa senhora que se encontrava enferma. A aposta é entendida pela criança como brincadeira, isso demonstra a inocência da menina, por sua vez, o Lobo demonstrando-se gentil, atencioso e amigável ao dialogar com Chapeuzinho Vermelho, propõe com um tom malicioso uma disputa mostrando-se preocupado ao afirmar o seguinte: "pois vou também visitá-la. Você segue por um caminho e eu por outro - e veremos quem chega primeiro" (LOBATO, 2002, p. 8). Segundo esta versão, enquanto o animal corria para chegar à casa da vovó, a menina tomou o caminho mais longo, além disso, foi parando para colher frutas do mato, correr atrás das borboletas e fazer raminhos de flores para levar à velhinha.

Envolvida pela distração dos passarinhos e borboletas, assim como, da colheita de flores, a menina lembrou-se do compromisso pelo qual havia sido enviado por sua mãe, que era, além de visitar, levar a cesta preparada com tanto carinho e cuidado. Resolve, então, partir ao encontro da velhinha. É exatamente "quando colher flores deixa de ser prazeroso é que o id, que busca o prazer, recua e Chapeuzinho Vermelho se torna ciente de suas obrigações" (BETTELHEIM, 2015, p. 240).

Ao chegar à casa da vovó, a menina percebe que algo estranho está acontecendo com a velhinha, mas por um certo momento acha normal, já que a boa senhora estava enferma.

https://periodicos.unifap.br/index.php/letras Macapá, v. 6, n. I, Io semestre, 2016. 


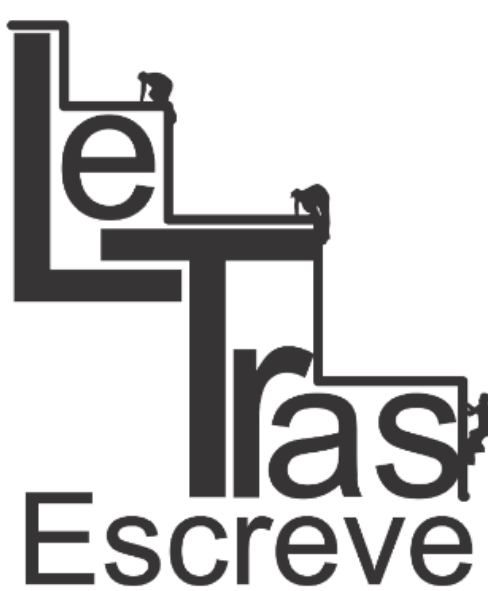

(ISSN 2238-8060)
Contudo, a curiosidade toma conta de Chapeuzinho Vermelho ao ponto de se admirar com a fisionomia daquela estranha criatura. A indiscrição lhe permite questionar o porquê daquela situação. "Que braços peludos a senhora tem, vovó! [...]. Que pernas compridas a senhora tem vovó! [...]. E que grandes orelhas, vovó! [...]. E que grandes olhos, vovó! E que grandes dentes a senhora tem, vovó!" (LOBATO, 2002, p. 10), assim, as indagações representavam uma forma de compreender o que estava se passando com a velhinha.

$\mathrm{Na}$ tradução de Walcyr Carrasco, há uma inversão em algumas palavras proferidas pela menina ao se dirigir ao Lobo, imaginando que fosse a velhinha. "Vovó, como são grandes os seus braços! É para abraçá-la melhor, minha netinha - respondeu o lobo, espertamente. Vovó, como são grandes as suas orelhas! É para escutar melhor a sua voz, minha netinha [...]" (CARRASCO, 2009, p. 5). O enredo continua a partir das indagações elucidadas por Chapeuzinho ao ponto que o animal se irrita e concretiza seu objetivo.

Por meio do diálogo, um tanto admirada, a menina tenta compreender o que está acontecendo com a velhinha, percebe que muitas mudanças são perceptíveis e em meio às dúvidas e, ao mesmo tempo, admiração, aguça os sentidos para tentar compreender as transformações sofridas pela senhora enferma. Entre uma fala e outra, entende-se que há a "enumeração dos quatro sentidos: audição, visão, tato e paladar; a criança púbere usa todos eles para compreender o mundo" (BETTELHEIM, 2015, p. 241). Esses sentidos são visíveis nos questionamentos de Chapeuzinho.

Corroborando com as ponderações supracitadas, Gabriotti (2009), afirma que na realização de história no contexto infantil há a apreensão da atenção, além de despertar a curiosidade, a imaginação, a criatividade e promove ainda o enriquecimento na vida interior da criança, pois, a auxilia a compreender melhor as suas emoções, porque assim como ocorre nas brincadeiras, as

https://periodicos.unifap.br/index.php/letras Macapá, v. 6, n. I, Io semestre, 2016. 
fantasias e os contos de fadas têm um papel extraordinário no seu desenvolvimento emocional.

Uma questão a ser discutida também a partir do conto é a cor vermelha, principal característica da menina. Na tradução de Lobato é denominada "Capinha Vermelha" e na de Carrasco, "Chapeuzinho Vermelho". Este é o título mais conhecido pelas crianças no contexto didático, porém, considera-se que a cor se acentua nos dois títulos e, consequentemente, nas versões traduzidas por ambos os autores.

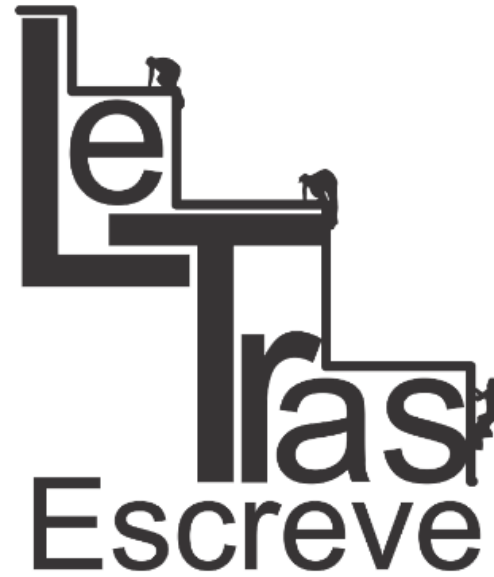

(ISSN 2238-8060)
O vermelho é a cor que simboliza as emoções violentas, incluindo as sexuais. O chapéu de veludo vermelho dado pela avó a Chapeuzinho Vermelho pode então ser visto como o símbolo de uma transferência prematura da atratividade sexual, que é ainda mais acentuada pelo fato de a avó ser velha e doente, demasiado fraca até para abrir uma porta. [...]. Ela demasiado pequena, não para usar o chapéu, mas para administrar aquilo que esse chapéu vermelho simboliza e aquilo que seu uso atrai. (BETTELHEIM, 2015, p. 242 - 243)

Destaca-se, ainda, que outra versão bastante conhecida é a apresentada pelos Irmãos Grimm, nesta, após serem engolidas pelo Lobo, a vovozinha e Chapeuzinho, o conto termina com a atitude voraz do animal. Com a chegada do caçador, a figura masculina passa a ser vista como o herói da trama, ocorre a partir daí o que chamamos de elemento maravilhoso comum nos contos de fadas, pois o caçador, em outras versões, lenhador percebe que a barriga do Lobo se mexia constantemente e, resolve abri-la, dando nova vida tanto à velhinha quanto à menina.

A abordagem de trabalho com os contos de fadas na formação da criança é uma questão necessária, uma vez que cumpre a função de aguçar a curiosidade, além disso, potencializa o pensamento infantil e fortalece o convívio entre os pais e seus filhos. Nesse sentido, não é somente função da escola possibilitar esses momentos de interação e compreensão da narrativa, entretanto, cabe também à família a realização dessa função. Toda e qualquer leitura de um texto traz uma informação nova, um ensinamento e, na concepção da criança, as adaptações são fundamentais e que sejam 
apreciadas por elas, de tal modo, há por parte da criança uma identificação com certas personagens que são descritas no enredo da história.

As crianças se identificam com a coragem do príncipe, a sabedoria do rei, a fragilidade da princesa e a maldade da bruxa. Todos nós temos estas características em diversas situações de nossa vida. Uma história prende a atenção, desperta a curiosidade, a imaginação e a criatividade, promove o enriquecimento na vida interior da criança, auxiliando-a a entender melhor as suas emoções. Assim como nas brincadeiras, as fantasias e os contos de fadas têm um papel importante no seu desenvolvimento emocional. (GABRIOTTI, 2009, p. 1)

Além dos elementos presentes na história o que desperta atenção e aguaça a curiosidade é a questão das ilustrações,

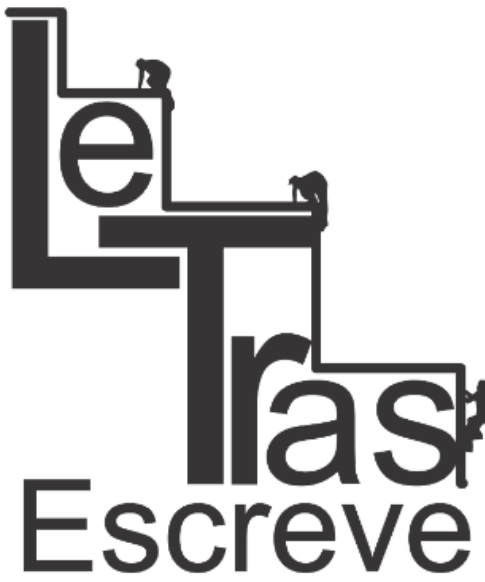

(ISSN 2238-8060) sobretudo, pelo jogo de cores. As imagens permitem à criança compreender melhor a narrativa e a auxilia na ampliação de sua imaginação, visto que, a arte de contar histórias é uma das vertentes de acessibilidade ao contexto literário adaptado à fase em que as crianças pequenas se encontram. E, nesse propósito, elas são colocadas diante das mudanças que vão ocorrendo ao longo da atmosfera narrativa.

O tempo em que Chapeuzinho se encontrou dentro da barriga do Lobo, representa um momento de maturação, em que a cor de seu capuz ganha um significado, isto é, representando a passagem da infância à adolescência. Diante desse elemento, o maravilhoso é evidenciado, quando a garota é retirada viva do estômago do animal, "ela renasce num plano mais elevado de existência; relacionando-se positivamente com ambos os pais, não mais uma criança, ela volta à vida como uma jovem donzela" (BETTELHEIM, 2015, p. 255).

Compreender os contos de fadas a partir da psicanálise permite que o professor amplie sua visão a respeito das histórias infantis e que seu conhecimento precisa ir além daqueles imaginados pelas crianças. A psicanálise no contexto escolar visa fortalecer a relação entre professor e aluno e, consequentemente, 


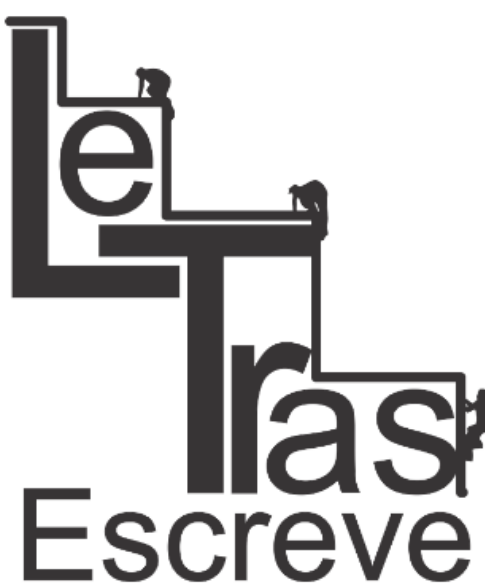

(ISSN 2238-8060) possibilita que o educador repense suas atitudes diante do trabalho com as narrativas infantis, ao passo que é necessário à criança a vivência de cada etapa formativa.

É fundamental que nas histórias contadas no contexto da sala de aula e ao longo da vida acadêmica, a criança tenha a oportunidade de escolha das leituras com propósitos diferenciados, pois, "um dos grandes méritos dos contos de fadas é que, ao ouvilos, a criança passa a acreditar que essas transformações são possíveis" (BETTELHEIM, 2015, p. 250) e, que aos poucos amadureça suas preferências.

Dessa forma, as narrativas nos impressionam pelos ensinamentos e por seu valor simbólico na construção da identidade infantil e que tanto a escola quanto a família precisam enxergá-las como forma de desenvolver as estruturas emocionais e o senso crítico da criança, permitindo-Ihe que a partir de suas seleções, seja aos poucos, inserida no contexto literário tendo como ponto de partida os contos fadas para que se projete o alvo de chegada nas leituras mais desafiadoras.

\section{Considerações finais}

Diante do exposto é possível compreender que há a necessidade de ampliação do olhar sobre as histórias infantis, bem como dos ensinamentos que esses contos possibilitam à formação da criança e à efetivação do senso crítico. É preciso inferir que a imaginação no processo formativo infantil pressupõe oportunizá-la das possibilidades de acesso às obras infantis, pois as possibilidades que inferem à formação leitora da criança devem começar desde os primeiros dias vida e com a sua maturação, outras leituras vão sendo apresentadas para que ela tenha a chance de construir um estilo próprio relacionado ao ato de ler.

Atualmente, as crianças têm uma gama de acessibilidade que as direcionem para a leitura. É cada vez mais comum encontrarmos

https://periodicos.unifap.br/index.php/letras Macapá, v. 6, n. I, Io semestre, 2016. 




(ISSN 2238-8060) adaptações dos clássicos infantis e suas traduções quer sejam para o cinema, quer seja na concepção de outros escritores e, as tecnologias, nesse sentido, cumprem, perfeitamente, a função de permitir esse acesso, além de ampliar as formas de leituras. Entretanto, é relevante que seja oferecida de maneira palpável a manipulação de livros, bem como o acesso às bibliotecas das quais a criança dispõe para que as pretensões de leitura corroborem com uma vivência leitora eficaz.

As considerações apresentadas por Bruno Bettelheim sobre o conto Chapeuzinho Vermelho, permitiu-nos compreender que há a necessária carência de olharmos as histórias infantis sob a perspectiva da psicanálise e que tais ponderações precisam estar refletidas nas atitudes docentes para que o estado emocional dos educandos amplie sobremaneira o processo de ensinoaprendizagem.

A leitura dessas narrativas desperta o senso crítico e aguça a imaginação infantil e, consequentemente, contribui com a formação da criança e aos poucos a insere no mundo literário. Os elementos evidenciados no enredo de Chapeuzinho Vermelho representam para os leitores infantis a certeza de que o bem caminha lado a lado com a obscuridade e que a desobediência da menina permite à criança entender que é necessária a obediência aos pais, o que fica latente que é possível ensinar por meios dos contos de fadas.

O desenvolvimento da psique humana na perspectiva das histórias infantis permitirá que a criança tenha a chance de vivência e compreensão, sendo, posteriormente, possível o amadurecimento nos gostos relacionados ao ato de ler, bem como das escolhas e dos estilos literários que melhor se adequam as suas necessidades. Dessa forma, a pretensão de realizar uma comparação entre duas versões de uma mesma história nos mostrou que que a ideia principal na ação adaptativa é mantida, contudo, outras informações são acrescidas permitindo à criança compreender de outra perspectiva a mesma história, o que enriquece as ações

https://periodicos.unifap.br/index.php/letras Macapá, v. 6, n. I, Io semestre, 2016. 
relacionadas ao enredo contado, pois o cesso à leitura além de ser visto como uma necessidade e representa ainda novas descobertas por parte dos leitores em situações iniciais de imersão de produção do conhecimento.

\section{Referências bibliográficas}

ABRAMOVICH, Fanny. Literatura infantil: gostosura e bobices. $5^{\text {a }}$ ed. São Paulo: Scipione, 2006.

BETTELHEIM, Bruno. A psicanálise dos contos de fadas. Tradução de Arlene Caetano. - 31 a ed. - São Paulo: Paz e Terra, 2015.

CARRASCO, Walcyr. Contos de Perrault: Chapeuzinho Vermelho e outras histórias. Barueri, SP: Manole, 2009.

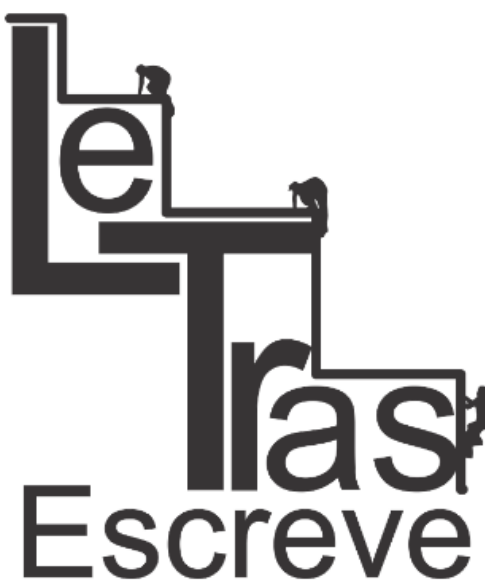

(ISSN 2238-8060)

COELHO, Nelly Novaes. O conto de fadas: símbolos, mitos e arquétipos. São Paulo: Paulinas, 2003.

GABRIOTTI, Roberta Barbero. A importância dos contos de fadas. 2009. Disponível em: <http://www.associacaocrianca.org.br/espacocrianca-familia/a-importancia-dos-contos-de-fadas.aspx>. Acesso em 16 abr. 2016.

PERRAULT, Charles. Contos de fadas. Tradução de Monteiro Lobato. $1^{\mathrm{a}}$ ed. $1^{\mathrm{a}}$ reimp. São Paulo: Companhia Editora Nacional, 2002.

POSTIC, Marcel. O imaginário na relação pedagógica. Rio de Janeiro: Jorge Zahar, 1993.

VOLPI, José Henrique. Estrutura psíquica da mente. Curitiba: Centro Reichiano, 2008.

Disponível em:

<http://www.centroreichiano.com.br/intranetcr/especializacao/2009/M 1/Aula1/INTRANET/Estrutura\%20psiquica\%20da\%20mente.pdf>. Acesso 16 abr. 2016.

Recebido em 16/07/2016. Aprovado em 07/08/2016. 